\title{
THE PHOTOGRAPH AS ACHEIROPOIETON
}

\section{A Copyright Perspective*}

\begin{abstract}
"La Photographie a quelque chose à voir avec la résurrection: ne peut-on dire d'elle ce que disaient les Byzantins de l'image du Christ dont le Suaire de Turin est imprégné, à savoir qu'elle n'était pas faite de main d'homme, acheïropoiétos?"
\end{abstract}

Roland Barthes ${ }^{1}$

This paper argues that the most faithful copy is the copy without an author. This hypothesis is suggested by a comparative examination of the status of asserted un-authored icons, the so-called acheiropoietai, and of photographs shortly after the invention of the new technology in the nineteenth century. Categories of copyright such as originality and authorship will be used to support the argument. As a preliminary remark the concession is imperative that it is in fact near impossible to create images, works, and copies that are not in some way or other the effect of an auctorial action - an authorless copy is thus a cultural construction. As such, however, this article endeavours to take it seriously.

\section{Faithful images: acheiropoietai and the icon}

The Decalogue (Exodus 20:4) commands (in the wording of the King James Bible): "Thou shalt not make unto thee any graven image, or any likeness of any thing that is in heaven above, or that is in the earth beneath, or that is in the water under the earth." Evidently, this comprehensive ban on images confronted Christian artists and their patrons with a theological and practical problem if they did not want to run the risk of being accused of idolatry. Theologians offered various solutions, which were repeatedly contested. While this is not the place to discuss the history and intricacies of iconoclasm in Byzantium or elsewhere, a specific type of image can be set apart for the purposes of this paper: the not

* This paper is part of a larger research project on the art history of copyright, supported by the Gerda Henkel Foundation, Düsseldorf.

1 Barthes 1980, 129. The translation in Barthes 1982, 82, is inaccurate in that it replaces the Shroud of Turin with St Veronica's "napkin"; see also Broadfoot 2012, 145 ("unfortunate omission"). 


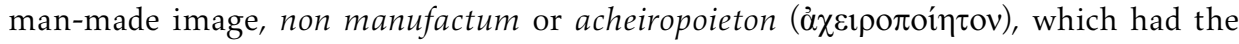
power to bypass the ban on man-made images. ${ }^{2}$ Ernst Kitzinger defines and refines this class of images as follows: "Acheiropoietai are of two kinds: Either they are believed to have been made by hands other than those of ordinary mortals or else they are claimed to be mechanical, though miraculous, impressions of the original." ${ }^{3}$ Theologically, acheiropoietai are without a human author, "produced miraculously by divine grace". ${ }^{4}$ In short, human authorship stands in the way of faithful images. As a consequence, faithful images had to be authored by the godly powers themselves. Ernst von Dobschütz has described these legends at length in his seminal study, Christusbilder. Some of the most famous examples from the sixth century, when these legends took form, include the impression of Christ's face and arms on the Column of Flagellation, as reported by a pilgrim, Theodosius; ${ }^{5}$ the image of Edessa, the so-called Mandylion, which was miraculously sent to King Abgar; ${ }^{6}$ the image of Camuliana, an image of Christ appearing in the water basin of a garden; finally the legend of St. Veronica, who gave Christ, who was carrying his cross to Golgotha, her veil that he might wipe his forehead - which he did, miraculously impressing his features on the cloth. ${ }^{8}$ Kitzinger distinguishes two aspects of the acheiropoietai: they are celestial by origin, and they can replicate themselves. ${ }^{9}$ Combining qualities of icon and relic, the acheiropoietai are perfect renderings of their subject; in fact they turn out to be their subject.

Their authenticity is part of their imaginative DNA, which can be transferred to the painted image. Dobschütz speaks of the significant predominance of the form against the material. ${ }^{10}$ An icon, in the words of Marie-José Mondzain, "will escape the function of reference; rather, it will itself become what is referred to." ${ }^{11}$ This becomes clear from an often quoted passage from the treatise on the Holy Spirit by Basil of Caesarea, written in the fourth century, where he draws a parallel between the unity of Father and Son and of the original prototype and the image:

For the Son is in the Father, and the Father is in the Son inasmuch as the former is like the latter, and the latter like the former, and in this lies their unity. So that by the peculiarity of their persons they are one and one, but in the community of their nature both are one. How then, if

2 See Belting 1994, 56; Dobschütz 1899, 37-39; Trilling 1998, 109 f.; Wood 2008, 39 ("a loophole in the Second Commandment's prohibition of images"). The idea of images sent from heaven predates Christian beliefs. Dobschütz begins his account with the Palladion: Dobschütz 1899, 1-3.

3 Kitzinger 1954, 113.

4 Mondzain 2005, 84. Indeed, these images share this quality with the depicted Christ, who was human but not "man-made"; cf. Belting 2005, $69 \mathrm{f}$.

5 See Dobschütz 1899, $71 \mathrm{f}$.

6 See Dobschütz 1899, 102-196; Wolf 2002, 22-24.

7 See Dobschütz 1899, 40-60; Mango 1972, 114 f., quoting Zacharias Rhetor: Historia ecclesiastica, XII, 4.

8 See Dobschütz 1899, 197-262. For a critical reading of the traditions of the vera icon see Wolf 2002.

9 Kitzinger 1954, $114 \mathrm{f}$.

10 Dobschütz 1899, 39.

11 Mondzain 2005, 66. 


\begin{abstract}
they are one and one, are there not two Gods? Because the imperial image, too, is called the emperor, and yet there are not two emperors: neither is the power cut asunder nor is the glory divided. And as the authority that holds sway over us is one, so the glorification that we address to it is one and not many, since the honour shown to the image is transmitted to its model. And what the image is down here by virtue of imitation, so the Son is over there by His nature. For just as in hand-made objects the likeness is by virtue of form, so is the case of the divine nature that is uncompounded the unity is in the communion of Godhead. ${ }^{12}$
\end{abstract}

This unity is part of the reason why holy images do not lose their celestial status even when a human takes over in the process of replicating the image. ${ }^{13}$ Indeed, icons are the best example of faithful copies in the Christian sense of the word "faithful". Faith was a precondition of the icons' claim to truth. ${ }^{14}$ The icons' faithfulness is so intense, and they remain so true to the acheiropoieton, because the artistic intervention of the icon painter, "by virtue of form" (Basil of Caesarea), is kept to a minimum. ${ }^{15}$ This did not only apply to icons copying acheiropoietai but other icons as well. Hans Belting explains that the
theological demand for 'truth' did [...] limit the scope of artistic production. 'Truth' was meant not in the sense of the art itself or of its imitation of nature but in the demand for authentic ar- chetypes. An archetype requires repetition, which thus explains the conservative dogmatism of icon painting. When an authentic form seemed to have been found, whether for a religious truth or for a 'genuine' portrait of Christ, there could be no other 'correct' solution. ${ }^{16}$

Despite all discernible stylistic and other distinctions, part of an icon's raison d'être was to be un-original. Christopher Wood - taking up earlier ideas by George A. Kubler - has described this phenomenon as substitutional chain or replica chain. ${ }^{17}$ It means that works of art gain their authority by claiming to be essentially identical to a prior instance. Gary Vikan speaks of a "remarkable conservatism" and concludes that the concept of the icon ignored its objecthood. ${ }^{18}$ From the perspective of modern day copyright law, this also ignores the object's maker: the author. Within the iconic replica chain and

12 Basilius, Liber de Spiritu sancto, PG, vol. 32, col. 149-152 [chapter XVIII, para. 45], the modern translation of the passage is taken from Mango 1972, 47.

13 Cf. Dobschütz 1899, 271 [my translation]: "These miraculous copies, which [...] are closely related to the idea of the imprint, mark significantly the difference between ancient and Christian beliefs. The diipetes must have fallen from the sky, otherwise it is false. The achiropoïte, however, can be conceived as the miraculous copy of a miraculously emerging original. Where the ancient legend had to assume robbery or purchase of the authentic idol, the Christian legend spoke of an impression, which was miraculously granted by divine grace to exceptional adoration."

14 Belting 2005, 49; Wood 2008, 38: "The actual manual copying from picture to picture, the transmission process [of the icon], is effectively taken on faith."

15 Cf. Wood 2008, 39. This does not hinder a certain stylistic change and evolution; cf. Brubaker 1995, 150; Gouma-Peterson 1995, 126: "within acceptable parameters painters were able to be both original and innovative"; Weyl Carr 1995, 121: "The story of the icon in Byzantium [...] is one of constant change".

16 Belting 1994, 19.

17 Wood 2008, 36, with reference to Kubler's The Shape of Time (1962) ibid., 37 f. Cf. Kubler 2007, 44-46, on "the invisible chain".

18 Vikan 1989, 47, 51; see also Dobschütz 1899, 54: "Es liegt im Wesen des Achiropoïtenglaubens, dass er gleichgültig ist gegen das wirkliche Objekt." 
its implicit notions of faithfulness and truth the creative function of the author is minimised. ${ }^{19}$

The spiritual and commercial values of an icon coincide; both are based on the assumption of material identity and the faith in the miraculous image. ${ }^{20}$ Even mass-produced small objects of personal devotion like cast-bronze icons of the Virgin and Child shared the spiritual value of the (absent) original model..$^{21}$ This monistic economy ${ }^{22}$ was dichotomised around 1500, when secular interests in art coincided with improved reproduction technologies and the consequential advent of copyright categories to the art market. Like the ancient Greeks and Romans, Byzantium knew no copyright law. ${ }^{23}$ The icon was authentic and authoritative but had no author in the Christian concept of admissible images. It served its purpose as a faithful replica, as an instance of the Godly original. This changed with the introduction of ideas of authorship and originality.

\section{The new order of art: originality and mimesis}

This change did not come about suddenly and complete but rather as a complex and gradual paradigm-shift on many levels, not always free from simultaneous incongruities. This is not the right occasion to trace all of its intricacies. Instead, this chapter will focus on two aspects mentioned in Giorgio Vasari's Lives of the Artists. Here, Vasari credits Giotto with the "naturalist turn" of the Renaissance,

that very obligation which the craftsmen of painting owe to nature, who serves continually as model to those who are ever wresting the good from her best and most beautiful features and striving to counterfeit and to imitate her [...]. [Giotto] became so good an imitator of nature that he banished completely that rude Greek manner and revived the modern and good art of painting. ${ }^{24}$

In this passage we encounter two of Vasari's grand narratives of art history in a nutshell. Firstly, the artist as author appears on the stage. Vasari's history is a history of great individuals. Demand shifts from faithful devotional works to works authored by promi-

19 In the terminology of Nelson Goodman $(1976,113)$, the icon is conceptually allographic but materially autographic.

20 Cf. Wood 2008, 41: "The entire European network of cult images was sustained by a collective agreement not to ask questions about when a panel was painted, how it was obtained, or when it might have been restored."

21 Vikan 1989, $49 \mathrm{f}$.

22 Mondzain 2005 does not explore the market for icons in Byzantium, as one could infer from the title of her book, but analyses the theological concept of economy.

23 While plagiarism was socially scorned in Greece and Rome, there did not exist any codification of a copyright: Dziatzko 1894, 561; Schickert 2005, 131-133; Choe 2010, 18, 29. According to Schickert, the creative process was considered a graceful gift from the Gods, not an autonomous individual achievement. This would indeed confirm the conceptual production framework of Byzantine icons.

24 Vasari 1912-15, vol. 1, 71 f.; transl. of Vasari 1568, vol. 1, 119. 
nent artists. The "rude Greek manner" following the replica chain of prototypes is interrupted and replaced by the requirement of original and innovative works. Secondly, while art remained "true", religion was relativised or even replaced by nature as object of reference. The modern artist should no longer strive to replicate the true image of God but instead imitate nature.

\section{Truth to nature}

In this way, faithfulness or truth remained an important artistic element, but religious truth, while continuing to play an important role, gave up its dominant aesthetic position to truth to nature. ${ }^{25}$ Even the term acheiropoieton had extended its meaning about 1000 AD to encompass nature and its objects. ${ }^{26}$ Peter Parshall speaks of a tension between inventive mimesis and factual documentation, between the image as a statement of fact and as a display of invention. ${ }^{27}$ Furthermore, creativity had to balance the Neo-Platonic critique of imitation. Copyright ideas played a role in negotiating the effects of this tension. A prominent example is the sixteenth-century case of a plagiarised Herbarium.

In 1533, Christian Egenolff published in Frankfurt a Kreuterbuch edited by Eucharius Rösslin. This book copied the illustrations from Otto Brunfels's Vivae icones herbarum, which had been published in 1530 by Johannes Schott, Egenolff's former colleague from Strasbourg. Schott had obtained an Imperial privilege protecting the publication (and his investment) for six years. Now he brought Egenolff before the Reichskammergericht (Imperial Chamber Court). Unfortunately no decision of the case is known, but we know that Egenolff defended himself by claiming that his Kreuterbuch was based on an old book, that not all the illustrations were identical in both books, that pictures of the same plants were likely to resemble each other, and that a privilege did not prevent other artists from depicting the same subject. ${ }^{28}$ Sachiko Kusukawa suggests that for Egenolff the true rendering of nature did not allow artistic license and could thus not be restricted by a privilege. ${ }^{29}$ In a second case, Egenolff copied illustrations from Leonhart Fuchs's De historia stirpium (1542) in his edition of Dioscorides's De materia medica (1543). Charged with new accusations of theft, Egenolff replied in a pamphlet against Fuchs that artists competed by emulating each other, but that God was the creator of nature and the artists merely imitated him: "ea gloria soli creatori debetur Deo, proxima pictori, qui earum lineamenta quamproxime imitatus fuit". ${ }^{30}$ Fuchs countered Egenolff's

25 On the history of the idea of mimesis see Tatarkiewicz 1980, 266-309.

26 Dobschütz 1899, 37 f., and ibid., Belege, no. 17a.

27 Parshall 1993, 555.

28 The case is reported by Grotefend 1881, $16 \mathrm{f}$. The documents are partially transcribed in an article by a "Gerichtsassessor Altona" from Meisenheim in 1892 (Altona 1892, 899-903) and have recently been summarised and contextualised by Sachiko Kusukawa (Kusukawa 2012, 87-90).

29 Kusukawa 2012, 87.

30 Egenolff 1544, b4v; see Kusukawa 2012, 89. 
"mocking insults" 31 with the argument that no two plants have exactly the same form, and two artists depicting the same plant would produce two different pictures. ${ }^{32}$

These two cases show that the view on nature was disputed. Nature could be seen as God's prototype, a kind of natural icon, indeed not made by human hand. In this perspective nature is the greatest acheiropoieton of all, and the artist can and must humbly imitate her. This claim, however, was no longer appropriate once artists turned their images into objects of their personal expression. They were now claiming authorship of that image next to - and as good as - God's authorship of nature ("alter deus"). Hans Blumenberg situates this self-consciousness in the figure of Nicholas of Cusa's layman from his Idiota de mente ("The Layman on Mind", 1450). Here, the humble act of carving spoons is compared to God's own creativity. ${ }^{33}$ As Blumenberg emphasises, this is a rare occasion of an account of creativity, which is situated within the sphere of technology. ${ }^{34}$ From the perspective of the history of intellectual property law, this is both interesting and meaningful, as, not long after Nicholas of Cusa's death, the first privileges were granted for technical inventions in Venice. ${ }^{35}$

\section{Originality of the artist}

If images are looked at as works of art instead of as objects of devotion, the substitutional chain and in a way also the spiritual power of the icon is broken. The object turns into the work of an individual author, the artist, where it had been the work of a faithful replicant of the true image, the vera icon. This is exactly the historic moment when ideas of copyright come to be viable. The history of art copyright is the history of the acknowledgement of artistic work and creativity as a commercial factor. When Marcantonio Raimondi reproduced Albrecht Dürer's woodcuts from his Life of the Virgin as copper engravings, he worked for a Venetian publisher selling devotional prints. ${ }^{36}$ Dürer's prints are an early example of images that on the one hand served a devotional function by their iconography and on the other hand became artistic products and collectibles by their authorship. ${ }^{37}$ These two social functions can overlap, but the distinction marks a development towards the modern idea of the autonomous creative artist. At first sight, the invention of mechanic replication processes steered by the printing press supported

31 Fuchs 1545, A3r.

32 Fuchs 1545; see Kusukawa 2012, 89.

33 See Blumenberg 1957, 268.

34 Blumenberg 1957, 268.

35 Cf. Frumkin 1945, 144; Kostylo 2010, 24-26; Mandich 1948.

36 See Pon 1998. Dürer's lawsuit against Raimondi brought before the Venetian Signoria is a Vasarian legend. However, the City Council of Nuremberg issued a decision on 3 January 1512 against a print seller who had offered counterfeited Dürer prints. See Petri 2014, 58-60.

37 Petri 2014, 53. Dürer was collected in Western Europe at large; examples include the collection of Ferdinand Columbus, see Landau 2003, 30. 
demand for identical devotional images. ${ }^{38}$ In a way, icons could now be mass-produced. Indeed, since the thirteenth century, when Pope Innocent III had granted remittance of sins to anyone who read the prayer "Salve sancta facies" to a copy of the Holy Face, there existed a market for images of Holy Faces for purposes of personal devotion. ${ }^{39}$ The advent of prints not only secured the supply of these Holy Faces but also their formal identity. A Head of Christ (fig. 1) dating from 1500/10 is a good example of this visual culture of devotion - it even includes the prayer.

However, the "new regime of print ${ }^{\prime 40}$ also shifted the meaning and reception of artefacts and artworks. It became part of the artistic job description to sever the replica chain and, on the contrary, forge an original and independent vision. Christopher Wood mentions Dürer as an example. ${ }^{41}$ Joseph Koerner has analysed the dialectical relationship between the acheiropoietic Holy Face and Dürer's prints and the famous self-portrait from the Munich Pinakothek. ${ }^{42}$ To create works of art meant to create something new. As a consequence, copies over the centuries assumed a more restrained position in the socially acceptable artistic process. For a considerable time the new perspective on the increasingly important artistic authorship co-existed with the demand for intact instances of a miraculous chain of images, until the aesthetic preference for the original invention also prevailed in the context of religious patronage. ${ }^{43}$ Ever permissible as a training measure within the framework of artistic education, ${ }^{44}$ the copy became unacceptable at the refined end of the increasingly secularised art market, while the common practice at the other end was being outlawed as piracy. ${ }^{45}$

This tension describes a fundamental condition of the economics of copyright. Today it feels natural that artists have the right to exploit their original works by producing reproductions for a wider audience or a different, even larger target group. From about

38 Wood 2008, 40.

39 Koerner 1993, chapter 5, 80-126.

40 Wood 2008, 13.

41 Wood 2008, $348 \mathrm{f}$.

42 See Koerner 1993, 85.

43 See Holmes 2013, $269 \mathrm{f}$. for the example of Alessandro Allori's reproductions of the miraculous image from SS. Annunziata dating from the $1580 \mathrm{~s}$, and the case of Domenichino's Last Communion of St. Jerome (1614), which was criticised for stealing its idea from Agostino Carracci's painting of the same subject (1592). On this case see Cropper 2005.

44 Writing around 1400, Cennino Cennini advised young artists: "strive and delight always to copy the best things that you can find, made by the hand of great masters" (Cennini [Broecke] 2015, 47). Although this advice was contested by modern and avant-garde artists, artistic training has never ceased to be an exception to copyright restrictions.

45 Here an extended aside remark is permissible. Prints convey yet another faithfulness, since mechanical reproductions are at least conceptually faithful instances of themselves. Such a reproduction is theoretically identical in every instance. Regardless of the question of faith to the original, these reproductions are mutually faithful. This concept is undermined by the discriminating eye of the connoisseur and amateur, who can spot differences and individualising features of different states of a plate and even characteristics of individual impressions. 


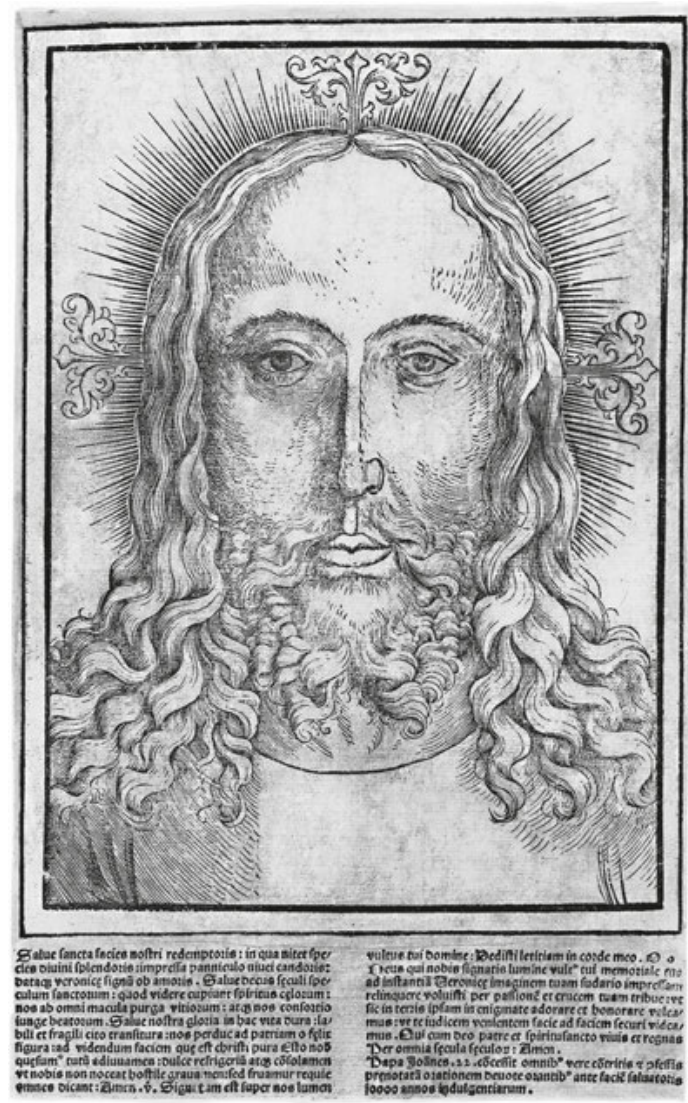

1 The Head of Christ, probably 1500/1510, woodcut, Washington, DC, National Gallery of Art, Rosenwald Collection, Accession No. 1943.3.521

1500 , this right could be protected against pirates and illicit copies by a privilege. ${ }^{46} \mathrm{~A}$ privilege is a kind of individual copyright, granted by the authorities. Indeed, in Germany Dürer obtained a privilege from the Emperor for his books in $1511 .{ }^{47}$ What started with printing privileges in Venice and Rome around 1500 developed into a more elaborate system of privileges adapting to the needs of the publishing trade (and others, mostly engineers). ${ }^{48}$ The economy of images had started to shift; originality and creativity commanded higher prices than faithful instances of an iconic prototype. The existence of an acknowledged author is what makes art different from the icon or works from a replica

46 The literature on privileges and their history is abundant. For an overview of the early history of artistic privileges in Italy see Witcombe 2004.

47 These were The Life of the Virgin, the second edition of the Apocalypse and the Small Passion. The privilege is mentioned in the respective colophon of the three books.

48 Cf. Kostylo 2010. 
chain. Usually it is the artist who wants to exploit his original by reproducing it - after all, this had been Dürer's main incentive when he set out to defend his investments and ideas with an Imperial privilege, and the situation was the same for Raphael, Titian, Rubens, and other artists who sought to protect their art from plagiarists and pirates. Copyright laws are the result of an economic analysis for the benefit of publishers, and the first publishers of images were the artists themselves.

The next important step in the genesis of a modern copyright law was made in the $18^{\text {th }}$ century. Then, the prints of the English artist William Hogarth were immensely popular and often pirated, interestingly not always accurately copied - some pirated editions were a paraphrase of the story told by Hogarth and not always close to the original. ${ }^{49}$ However, they affected Hogarth's share of the market negatively, and he started a campaign for better legal protection. Hogarth contributed to a petition entitled The Case of Designers, Engravers, Etchers, $\mathcal{E}$ c., which was published early in 1735 (N.S.), and which stated that the print shops themselves sold pirated copies to their customers. ${ }^{50}$ It continued:

If it be considered what it is that gives an Artist the Right to the Profits of his own Designs, Prints, \&c., it will easily appear that these Copyers are no better than the Lowest of Robbers. [...] It is humbly hoped it will be thought proper to make it punishable by Act of Parliament for any one to copy the Designs of Another. ${ }^{51}$

Hogarth's intense lobbying efforts were successful when the English parliament protected the work of original engravers in the so-called Hogarth Act in $1735 .{ }^{52}$ It protected "every person who shall invent and design, engrave, etch, or work in Mezzotinto or Chiaro Oscuro, any historical or other print or prints [...] for the term of fourteen years". ${ }^{53}$ In the framework of this first copyright act for visual artists, the paradigm shift was completed: the act protected those who invented something and who did not copy, those who created something new. ${ }^{54}$

\section{Both true to the original and creative: the engraved reproduction}

In The Case of Designers, Engravers, Etchers, $\mathcal{E}^{\prime} c$., Hogarth had argued against the originality of reproductive engravings:

49 Dabhoiwala 2012; Kunzle 1966.

50 Hogarth 1735, 2; see also Journal of the House of Commons, vol. 22, 364. Under the Julian calendar in use in England until 1750, the new year started on 25 March, which is why the entry in the Journal is for 1734 .

51 Hogarth 1735, 2, $4 \mathrm{f}$.

52 On Hogarth and the genesis of the Engravers' Act see Deazley 2004, 88-94; Kunzle 1966, 311-318; Paulson 1992, 35-47; Rose 2005.

538 Geo. II, c.13.

54 Cf. Rose 2005, 64; for a cultural contextualisation see Mortier 1982. 
[I]n taking a direct Copy of a Design, there is absolutely no Skill in Designing requir'd. It is to be done mechanically, by one who knows nothing of the Business. [...] They have likewise Mechanical Ways, by the Assistance of Rulers, \&c. to take Copies of Prints, both of larger and smaller Sizes than the Original [...]. ${ }^{55}$

This passage defines the exact copy as un-original. The faithful copy of an engraving apparently does not need an author, as it is mechanically conceived and made. While this is (almost) true for reproductions of prints, the case is different for prints reproducing paintings: while easily being identifiable as reproductions of a certain painting, they cannot render all aesthetic characteristics of their original. Materiality, colour, orientation and contrasts are but a few of the features which pose a problem to the reproductive engraver. As soon as the reproductive medium is different from the reproduced medium, these differences become obvious. ${ }^{56}$

The original Hogarth Act did not protect reproductive engravings. However, opposite to the logic of deficiencies or of technological progress, many artists and writers were of the opinion that the reproductive engraver undertook a very creative act in itself. Barbara Stoltz mentions Giovanni Baglione's chapter on the Vite degli Intagliatori in his Vite de' Pittori, Scultori et Architetti (1642) as an example of writings that consider the reproductive engraving a creative practice. ${ }^{57}$ Later, legislators took account of the fact that also the reproductive engravings were the product of creative work. In the UK the updated Engravers' Copyright Act of $1766^{58}$ also protected reproductive engravings. However, it had to be corrected in 1777 to protect only those reproductions that had been consented to by the author of the original. ${ }^{59}$

Not only in the United Kingdom but also in France, views on copyright changed. Perhaps here the views on the creative powers of engraving were the most advanced and pertinent in Europe. After having dissolved the Guild of St. Luke, Louis XVI guaranteed certain artist's rights in the Déclaration en faveur de l'Académie Royale de Peinture et de Sculpture of 1777. Its article 8 stated that engravers needed the approval of the original artist to produce a reproduction, but it also declared that those reproductions were not allowed to be reproduced again. The revolutionary décret-loi of 19-24 July 1793 protected all "works of genius", which included reproductive engravings, since they did create something new.

The situation in the German-speaking states was more complicated, and the history of their copyright legislation shall not be told here. ${ }^{60}$ The first state to protect engravings

55 Hogarth 1735, 4.

56 Gramaccini/Meier 2003, 64-79, reproduce a sequence of exemplary comparisons.

57 Stoltz 2010, 254.

587 Geo. III, c.38.

5917 Geo. III, c. 58; see Rose 2005, 65.

60 Here only select examples from the bibliography on the subject can be offered: for a contemporary survey on German artistic copyright see Wächter 1877; for a general study on German copyright history between 1450 and 1850 see Vogel 1978. 
was Prussia, whose act of 1837 took up the double nature of the reproductive work of art - the artist of the original work retained the reproduction rights, and the reproducer was protected against pirated reproductions. ${ }^{61}$

A reproductive engraving now had two authors, the creator of the original work of art and the engraver, who was largely seen as a kind of translator. ${ }^{62}$ This activity was by and by considered to be artistic and creative, and it was understood that such an engraving also allowed for artistic license in some aspects. ${ }^{63}$ In other words, some of the deficiencies of reproductions such as the exact reproduction of colour values were rebranded as pockets of freedom for creativity. These creative copies enjoyed copyright protection of their own. Notwithstanding, the aura of the original did not allow for much creative potential in the reproductions: engravings and other handcrafted reproductions were inherently untrustworthy in the unpredictable manner that they reported facts. ${ }^{64}$ In 1893 Bernard Berenson singled out the problem of accuracy: "No engraver, however well intentioned, can help putting a great deal of himself into his reproduction." 65 From this technical perspective, faithful reproductions remained a sequence of problems to be solved until the copy was technically perfect. One could also say it is the logic of progress, or in Christopher Wood's words, the conversion of representation into an engineering problem. ${ }^{66}$ Accordingly, French printers and engravers made remarkable efforts to reproduce colour in the late eighteenth century, ${ }^{67}$ but it was only the advent of photography as a new reproductive medium which brought about a paradigm shift.

\section{The mechanics of the photographed image unprotected by copyright}

Henry Fox Talbot's Pencil of Nature, published between 1844 and 1846, contained a "Brief Historical Sketch of the Invention of the Art" (of photography), which starts with Fox Talbot's account of how he wanted to sketch the landscape of Lake Como with the help of a camera lucida, but "I found that the faithless pencil had only left traces on the paper melancholy to behold." 68 Characteristically, the author or draughtsman is the

61 Gesetz zum Schutze des Eigenthums an Werken der Wissenschaft und Kunst gegen Nachdruck und Nachbildung, in: Gesetz-Sammlung für die Königlichen Preußischen Staaten, Berlin 1837, Nr. 22, 165-171. A legal commentary on the new law, which was published immediately after it had come into force, is Hitzig 1838.

62 Cf. Gramaccini/Meier 2003, 56. The historical discourse is too complex to be outlined here. A prominent opponent to the creative status of reproductive engravings was Quatremère de Quincy; see Michel 2007, 592-596.

63 Cf. Delaborde 1856, 621: “La gravure est un art, précisément parce qu'elle permet, qu'elle exige même la participation de la pensée et du goût à un travail de reproduction."

64 Fawcett 1986, $185 \mathrm{f}$.

65 Berenson 1893, 346.

66 Wood 2008, 40.

67 See exh. cat. Washington, DC 2003.

68 Fox Talbot 1844, [4]. 
source of - not even artistic - license, which makes it impossible to render nature faithfully. While the pencil remains faithless, ${ }^{69}$ the photographic process becomes the faithful alternative, purportedly letting nature herself produce the image and presenting us with the "inimitable beauty of the pictures of nature's painting"70. Photography not only promised to solve the aesthetic problem of truth to nature but also the problem of the faithful reproduction, which is true to the original. This double solution ruled out the conceptual role of the artist. Despite the unquestionable technical problems of the first reproductive photographs, ${ }^{71}$ the medium promised the rebirth of the un-authored image guaranteeing a true reproduction.

Two early legal cases (of a potentially much longer list) can serve to illustrate the view that a photograph was the product of an automated process, and as such produced more accurate copies, at least of black and white prints. In 1855 a court in Berlin deemed photography a purely mechanical medium of reproduction in a case involving pirated photographic reproductions of an engraving. ${ }^{72}$ In a similar case in England, the London based art dealer Ernest Gambart sued a Mr Ball, who had sold illicit photographs of Thomas Landseer's engraving of The Horse Fair by Rosa Bonheur. The court argued that photography was "the most perfect of all known modes of taking copies: every line and every shade is reproduced exactly as in the original". ${ }^{73}$ This was evidently an exaggeration for photographs in general but true for photographs of black and white engravings. ${ }^{74}$ Again, in this case the photograph played the role of a technology that made the truest possible copy.

As photographs were not deemed to have an author, they could not be protected under copyright law. For dealers wanting to capitalise on the new technology, this posed a problem: when the London-based dealer Ernest Gambart tried to sell photographs of Rosa Bonheur's Shetland Ponies, he had to admit that his investments were fruitless. ${ }^{75} \mathrm{In}$ England, photographs were not yet enlisted in the catalogue of copyright protected media, and in France and the German states, photography had yet to be considered a creative medium. Photographic studios and publishers tried to intervene in a debate that in some regards had already established the truth that photography was not an art. In lieu of the numerous contemporary statements, one of the more famous quotations by the French author Alphonse de Lamartine must serve the purpose. In 1841, Lamartine

69 Delaborde 1856, 624, describes the engraver's burin in similar terms: "un burin débile ou volontairement infidèle". He remained, however, sceptical and did not regard the photograph's "mathematical faithfulness" the last word in art reproduction.

70 Fox Talbot 1844, [5].

71 See contribution by Helmut Hess in this volume. Also, the problem of representing colour persisted for some time; Londe 1888, 90: "on ne peut pas encore reproduire [les couleurs] en vraies valeurs d'une manière parfaite."

72 Ricke 1998, 36 f.

73 Gambart v. Ball, 14 Common Bench Reports (New Series), 306 (311).

74 Cf. Delaborde 1856, 625 f., on photographing drawings and prints; critically ibid., 631.

75 Gambart 1863, $19 \mathrm{f}$. 
had been the author of a report on a copyright law project. In December 1858 he famously remarked that photography with its slavish precision would never be an art but only an optical plagiarism of nature, "un plagiat de la nature par optique": "Mais où est la conception de l'homme? où est le choix? où est l'âme? où est l'enthousiasme créateur du beau? où est le beau? Dans le cristal peut-être, mais à coup sûr pas dans l'homme."76 With these words, Lamartine describes photographs as inhuman works, products of chemistry. He was not alone in criticising the new technology as artless. Copyright theory had widely appropriated this opinion. For many nineteenth century lawyers, the photograph was the prototype of a "not new" image, in the sense of "not original", and the legislators acted accordingly.

In Germany, the Act for the Protection of Photographs from 1876 was conceived as a parallel act to the Act for the Protection of Works of Art, but did not offer the same level of protection: photographs were only protected for five years $(\S 6)$ and only against mechanical reproduction, or photographs $(\S 3)$, whereas "true" works of art enjoyed a protection term of the artist's life plus 30 years. Photographs of copyrighted works of art were not protected at all $(\S 1)$, as copyright pertained to the author of the original work. Photographs of works of art in the public domain were protected as any other photograph. ${ }^{77}$ As Stefan Ricke rightly observes, the Act avoided the term "author" ("Urheber") to describe photographers. ${ }^{78}$ Photographs were generally not accepted as art but given a comparatively meagre protection.

In France, the copyright law of 1793 protected a "production de l'esprit ou du génie" only, and it was widely debated whether photography was such a product. French law courts never decided the matter on a principal level. When in 1862 the photographic firm of Léopold-Ernest Mayer, Louis-Frédéric Mayer and Pierre-Louis Pierson sued the photographers Pierre Eugène Thiébault and Pierre Alexis Marcelin Betbéder, and the art dealer Schwalbé for contrefaçon of some of its photographs, notably portraits of the Count of Cavour and Lord Palmerston, the final verdict by the Cour de cassation ruled that a photograph could be a protectable work of art and that it was for the courts to decide on a case-by-case basis whether the photograph in question was a "work of spirit or genius" or merely mechanical. ${ }^{79}$

British legislation bypassed this problem, as its laws were not based on the assumption of a creative act but on the right to copy and reproduce works of art, literary and other. Perhaps the distinction between the Anglo-American copyright system and the continental system of author's rights is best visible in this historical moment of 1862 , the

76 Lamartine 1858, Entretien 36, $410 \mathrm{f}$.

77 See Ricke 1998, $111 \mathrm{f}$.

78 Ricke 1998, 113; cf. Klostermann 1876, 80, explaining that photography was not regarded an artistic process.

79 Cour de cassation (28 November 1862), Dalloz Jurisprudence générale 1863, 1, 53-55 (54-55). On the case see Girardin/Pirker 2008, 28 f.; McCauley 2008, 64-67; Rooseboom 2008, 296 f. 
year of the introduction of the Fine Arts Copyright Act in the United Kingdom. The act protected photographs irrespective of the status of the image as art or industry ${ }^{80}$ until 1st July 1912, when the Imperial Copyright Act came into force and photographs were submitted to a more discriminating copyright regime. ${ }^{81}$

Thus, at the time of growing commercial relevance of reproductive photographs in the late nineteenth century, the position of the author differed in the copyright laws of the three mentioned countries. In the UK the photograph's author was irrelevant until 1912. In Germany the photographer was not accepted as author. In France the courts assessed photographs on an individual basis, questioning whether they were artful and consequently had an author or not. Photography was generally regarded as a medium to (re-)produce faithful copies, because it seemed to minimise the human factor. This alienated the medium to the categories of copyright. To create nothing new is a legal impossibility in a copyright framework, since "creating" here means "to make something new and original". ${ }^{82}$ An image can either be created and is new in the sense of a copyrightable original, or it is simply made, and then it need not be new. The English expression "faithful copy" reveals a connotation the German counterpart "treue Kopie" does not, namely the belief in something miraculous, inexplicable, mysterious, and incomprehensible. In its early days the photograph shared these characteristics with a historical precursor, the image not made by human hand. The invention of the photograph indicated the return of the acheiropoieton.

\section{The acheiropoietic photograph of the Shroud of Turin}

Indeed both worlds met in an anachronistic clash in May 1898 when the Italian lawyer and amateur photographer Secondo Pia took photographs of the Shroud of Turin. ${ }^{83}$ According to carbon-14 dating conducted in 1988, the shroud was originally made between 1260 and $1390 .^{84}$ The details of its image are not easily distinguishable. Pia's negative of the photograph supposedly gave the impression of a positive image (fig. 2 ). ${ }^{85}$ In the view

80 See Deazley 2003, 237; McCauley 2008, 68-70.

811 \& 2 Geo. V, c. 46; cf. McCauley 2008, 70.

82 Cf. Petri 2013.

83 See Zaccone 1998, with further references. Secondo Pia's own account, the "Mémoire sur la reproduction photographique du saint Suaire de Turin dans le soir du 28 mai 1898" was printed in Loth 1910, 17-21, in his own translation. For a thorough analysis of the photographic framework of the shroud around 1900 see Geimer 1999 and the slightly revised German version in Geimer 2010, $175-251$.

84 See Damon/Douglas [et al.] 1989. Those results have not been successfully contested; see the references in https://en.wikipedia.org/wiki/Radiocarbon_14_dating_of_the_Shroud_of_Turin (last access 1 July 2015).

85 See Loth 1900, 40; Vignon 1902, 11; cf. Geimer 2010, 182, commenting that the surprise that met Pia's negatives was slightly bewildering, since dark traces on a shroud will inevitably render as light traces in a negative. 
2 Secondo Pia, photograph of the Shroud of Turin, 1898, detail

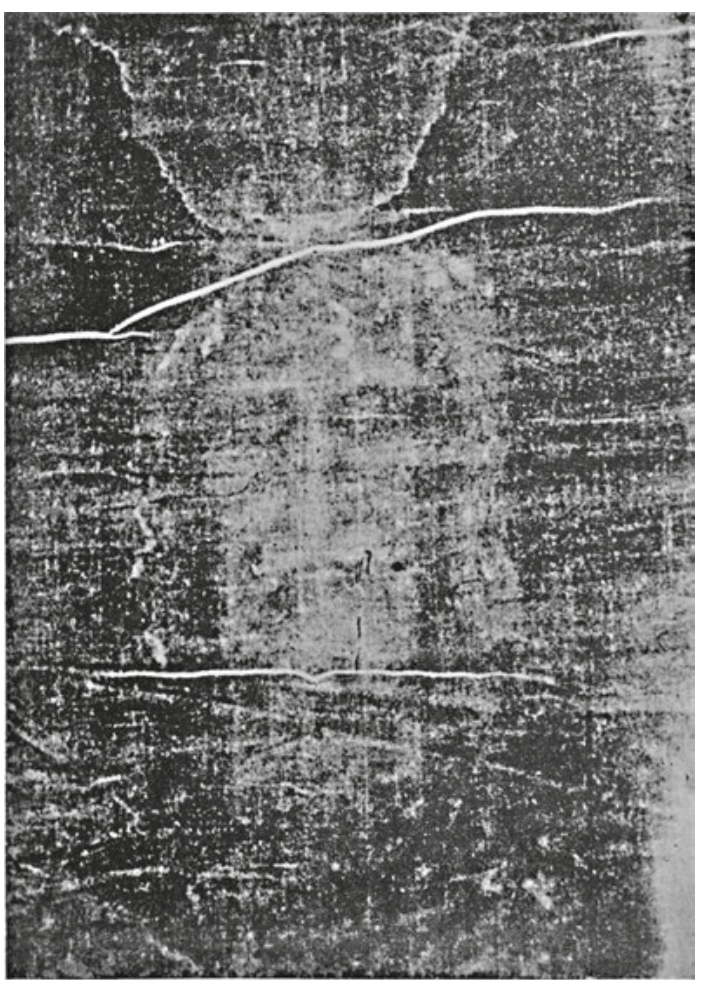

of several writers, the mechanics and chemistry of the photograph had made visible the features of Christ, which were perceived to have been photographed on the fabric by their own miraculous powers: "Ce suaire est donc comme un cliché photographique." 86 The shroud became a négatif objectif, an object with the characteristics of a photographic negative. ${ }^{87}$ Pia's new photographs, quickly reproduced and distributed as albumen prints on cardboard ${ }^{88}$ proved the discovery of a hidden photograph in the shroud.$^{89}$ Furthermore, it was first with these photographs that the shroud became intelligible ("[la] reproduction photographique [...] le montrait plus exactement qu'on n'aurait pu le connaître par les yeux $\left.^{\prime \prime 90}\right)$, if only in the shape of reproductions in different techniques implying different

86 Loth 1900, 41.

87 Loth 1910, 4. The terminology was not yet developed in Loth 1900, 39-42.

88 See exh. cat. Turin 1998, no. 21.

89 Belting 2005, $64 \mathrm{f}$.

90 Loth 1910, 8; cf. Loth 1900, 26: "La photographie avait pénétré ce que l'œil ne pouvait voir [...]."; "les mille détails imperceptibles à l'œil, [...] que seul l'appareil photographique voit", ibid., 45. 
grades of retouching and image processing. ${ }^{91}$ For some authors, the authenticity of Pia's photograph informed and confirmed the authenticity of the "real" image of the shroud, as exemplified in one of the early books on the subject by Arthur Loth, published in 1900: "la photographie nous a révélé que le Saint-Suaire n'est point une peinture, ni une copie faite de main d'homme d'après un original quelconque ou avec l'imagination d'un artiste. ${ }^{92}$ Peter Geimer reminds us that the topos of deficient graphic arts was prevalent in the late $19^{\text {th }}$ century, and that photography was deemed to heal that deficiency. ${ }^{93}$ In the words of Arthur Loth, the process was very straightforward, as the image of Christ had been "simplement copié", ${ }^{94}$ first on the shroud, then in the photograph. The shroud is a faithful copy in both senses of the word. Its ostensible embodied photographic process reflects the ancient cultural technique of the acheiropoietic image: 95 "it must be recognized that the figures on the Holy Shroud are in no sense the work of man." ${ }^{16}$ Other authors were more sceptical. In his pamphlet, Le saint Suaire de Turin est-il l'original ou une copie?, Ulysse Chevalier did not make photography the subject of his discussion but concluded that the shroud was a medieval fake from an analysis of sources, ${ }^{97}$ whereas Adolphe-Louis Donnadieu faced the problem of the fallacy of the photograph in the first lines of his critical book on the subject. ${ }^{98}$ Donnadieu also deconstructs the concept of "simple copy" by pointing out that the conditions of taking the photograph were not ideal. He attributes the positive impression of Pia's negatives to varying sensitivities of photo-chemical substances to certain colours, the resulting orthochromatic aberrations, and to considerable overexposure. ${ }^{99}$ While the photographer may have been acting in good faith, this faith is not enough to guarantee a perfect copy. ${ }^{100}$ Here Donnadieu reinstates the author as the cause of the photograph, with all the deficiencies of a traditional artist that Paul Vignon singles out as having been set aside by the alleged acheiropoietic photo-

91 Didi-Huberman 1984, 65; Geimer 2010, 222 f.; Kaenel 2001, 89-91. Vignon 1902, 110, maintained that the processing of Pia's original negative were unaltered reproductions.

92 Loth 1900, 39; cf. Belting 2005, 66. Kaenel 2011 appears to confound the two publications by Loth (1900 and 1910).

93 Geimer 1999, 85; cf. Loth 1900, 50: "l'absolue perfection mécanique". This was not true for all, as Walter Benjamin (Benjamin 1972, 5 f.) reminds us. He cited an article supposedly from the the German newspaper Leipziger Anzeiger claiming that photography was blasphemy, and that "God's image cannot be captured by any human machine." While the article is a piece of fiction by Max Deuthendey (1867-1918), its underlying arguments remain important; see Kemp 1980, 68.

94 Loth 1900, 45.

95 On the concept of cultural techniques, a translation from the German "Kulturtechniken", see Winthrop-Young 2013.

96 Vignon 1902, 125.

97 Chevalier 1899.

98 Donnadieu 1903, 1; Geimer 2010, 206 et passim, quotes his name as Adrien Donnadieu, which is not correct.

99 Donnadieu 1903, 56-58; cf. Geimer 2010, 221-232.

100 Donnadieu 1903, 26: "L'auteur [...] a copié le sujet tel qu'on le lui a présenté, tel qu'on lui a permis de le copier. Il a été de très bon foi, mais on le lui a mal présenté, on le lui a fait copier dans de mauvaises conditions." 
graphic process of the shroud. ${ }^{101}$ Indeed, experts knew how to "manipulate the image at almost every stage from initial choice of process, lens, viewing angle and distance, lighting, focus and exposure, through all the procedures of developing and perhaps retouching, down to the final printing and presentation."102

Arguably, the status of the shroud depended - and depends - on the faith of the spectator, which is also true for an icon or an acheiropoietic image (or, by the way, for autographic works of art like original oil paintings ${ }^{103}$ ). Indeed, as Roland Barthes has famously remarked in his original Chambre claire, the Shroud of Turin is a photographic acheiropoieton. ${ }^{104}$ Philippe Kaenel has described Barthes' remark as a returning footnote to André Bazin's Ontology of the Photographic Image: "Let us merely note in passing that the Holy Shroud of Turin combines the features alike of relic and photograph." ${ }^{105}$ Indeed this understanding can be traced back to the first statements on the 1898 photographs of the shroud. ${ }^{106}$ A few of the early authors on the shroud's photographs explicitly placed them in the tradition of the acheiropoieton: Ernst Dobschütz and Fernand de Mély. ${ }^{107}$ The photographic process successfully replaces the author in the conception of the image. Furthermore, the photograph replaces its reference, as the miracle was found in Pia's negative, not in the shroud itself - an acheiropoietic mise en abyme. ${ }^{108}$ More practically, if one concedes a copyright for reproductions of two-dimensional works such as Secondo Pia's photographs of the shroud, that copyright has expired in 2011, 70 years after Pia's death in 1941. For a truly miraculous un-authored image, however, no copyright would have been legitimate. In the universe of the acheiropoieton, Pia's photographs did not create anything new, they revealed the original image. Fittingly the patron saint of photographers is St. Veronica. ${ }^{109}$

\section{Conclusion: faith in the un-authored copy and the miracle of St. Nikon}

For the faithful, the acheiropoietai, the images allegedly made without the touch of the human hand, were miraculous phenomena. At its early stages, photography was com-

101 Vignon 1902, 30: "No painter, in his most elaborate work, has ever risen to such exactitude". Cf. also the comments by Geimer 1999, 72, on Vignon's book.

102 Fawcett 1986, 191.

103 Malkan 2005, 458.

104 Barthes 1980, 129.

105 Kaenel 2011, 76; Bazin 1960, 8. On the connection between Bazin and Barthes see also Broadfoot 2012, 146 f. Mondzain 2005, 202, observes a "sort of lexical traffic between a technological vocabulary and a spiritual vocabulary".

106 Geimer 2010, 203-205.

107 See Dobschütz 1899, 76; de Mély 1902, 47.

108 Geimer 1999, 73 f.; Kaenel 2011, 83. Donnadieu 1903, 174, demanded that the shroud itself should be investigated, not the photograph.

109 She was chosen by the vote of a number of French photographic societies in 1897; Anonymous, $1898,368$. 
monly considered just as mysterious. While the mechanism was man-made, the production of the image to a certain extent no longer was. The object of a main current of modern aesthetic faith, nature, was now herself able to produce images: "on est en présence, non d'une copie, mais d'une représentation originale, faite d'après nature [...]."110 While this statement about the Shroud of Turin conflates nature and Christ as image-processing entities, it points back to the Pencil of Nature and confirms the understanding of photography as an authorless technique. However, photography is no longer understood as part of nature.

Acheiropoietai and photographs stood, conceptually, at the margins of continental copyright law. Coincidentally, a Japanese camera brand and a Byzantine Saint share the same name. When St. Nikon died, an admirer, John Malakenos, commissioned a portrait of the saint from a painter, and described the Saint to him in detail. The artist, however, "was unable, from the description alone, even though trained to the height of his art, to paint in exact likeness what he hadn't seen." One day, the Saint appeared to the painter. As soon as he realised who had entered his studio, he quickly turned to the tablet

which he held in order to impress the image he saw - Oh! the miracle! He sees the holy form of the thrice-blessed automatically impressed on the tablet. Astonished therefore at this he turned around toward the saint quickly, saying with great fear 'Lord have mercy.' But he no longer saw him; for the blessed one had at once vanished. And the painter added the remaining colours to the outlined resemblance and brought the icon to completion. ${ }^{111}$

While the Japanese camera was not named after a Byzantine Saint with a photographic afterlife - "Nikon" was introduced as a compact camera brand in 1946, being a variation of Nippon Kōgaku Kōgyō Kabushikigaisha (日本光学工業株式会社, “Japan Optical Industries Corporation") - the final "N" in "Nikon" was added to allude to Zeiss' brand "Ikon". ${ }^{112}$ The coincidence makes perfect acheiropoietic sense, particularly as there is no apparent author for it. In Ernst Dobschütz's words, "Faith in [the acheiropoietai] was stronger than their own power."113 James Trilling's conclusion that in Byzantium, miraculous images emerged spontaneously, because people knew what to look for, ${ }^{114}$ points at the spectator as the $a d-h o c$ and ephemeral author of an apparition and to the timelessness of acheiropoietai, which photography cannot prevent. Quod erat demonstrandum in our own age of images of the Virgin appearing on American "grilled sandwiches". ${ }^{115}$ Today, the

110 Loth 1900, 48.

111 Sullivan 1987, no. 44, 152-155.

112 See https://en.wikipedia.org/wiki/Nikon\#Names_and_brands (last access 1 July 2015). The article also points out that "Nikko" coincidentally means "sunlight".

113 Dobschütz 1899, 51. Georges Didi-Huberman (1984, 65; 1997, 52 f.), reintroduces Benjamin's concept of the aura to the miraculous reproductive process.

114 Trilling 1998, 126.

115 In 1994, the darker parts of a toasted sandwich formed the image of a female face in the household of Diane Duyser from Florida. For references for this and other examples of apparitions of Christ, Mary and religious symbols see https://en.wikipedia.org/wiki/Perceptions_of_religious_imagery_in_natural_phenomena (last access 1 April 2015). 
U.S. Copyright Office pragmatically states that "To qualify as a work of 'authorship' a work must be created by a human being [...]. Works that do not satisfy this requirement are not copyrightable. The Office will not register works produced by nature, animals, or plants." ${ }^{116}$ Or by God, as this definition also excludes acheiropoietai. Moreover, reproductions not conceived by human hand remain outside the scope of modern copyright law. They can be authorised but never authored. ${ }^{117}$ An author brings his individual personality with him and thereby undermines the aims of the faithful copy. The most faithful copy is the un-authored copy.

\section{Bibliography}

Altona, [Gerichtsassessor]: Aus den Akten des Reichskammergerichts, in: Zeitschrift für die gesamte Strafrechtswissenschaft, 12.1892, 898-913.

Anonymous: Photographic Miracles, in: The Process Photogram, 5.1898, 368-370.

Barthes, Roland: Camera Lucida. Reflections on Photography, transl. by Richard Howard, London 1982 [first published as La chambre claire: note sur la photographie, Paris 1980].

Basil of Caesarea: On the Holy Spirit, transl. by George Lewis, London 1888 [originally written c 375].

Bazin, André: The Ontology of the Photographic Image, in: Film Quarterly, 13.1960, 4-9 [first published in French as: Ontologie de l'image photographique, in: Les problèmes de la peinture, ed. by Gaston Diehl, Lyon 1945].

Belting, Hans: Likeness and Presence. A History of the Image Before the Era of Art, Chicago 1994 [first published in German as Bild und Kult. Eine Geschichte des Bildes vor dem Zeitalter der Kunst, Munich 1990].

Belting, Hans: Das echte Bild. Bildfragen als Glaubensfragen, Munich 2005.

Benjamin, Walter: A Short History of Photography, in: Screen, 13.1972 (1), 5-26 [first published in German as: Kleine Geschichte der Photographie, in: Die Literarische Welt, 7, 18.9., 25.9., 2.10.1931].

Berenson, Bernard: Isochromatic Photography and Venetian Pictures, in: The Nation (New York), 57, 9 November 1893, $346 \mathrm{f}$.

Blumenberg, Hans: "Nachahmung der Natur". Zur Vorgeschichte der Idee des schöpferischen Menschen, in: Studium Generale, 10.1957, 266-283.

Broadfoot, Keith: Barthes's Religious Substance. Photography and Acheiropoietos, in: Image \& Narrative, 13.2012, 141-154.

Brubaker, Leslie: Originality in Byzantine Illumination, in: Originality in Byzantine Literature, Art and Music. A Collection of Essays, ed. by A. R. Littlewood, Oxford 1995, 147-165.

Cennino Cennini: Cennino Cennini's Il libro dell'arte. A New English Translation and Commentary with Italian Transcription, ed. and transl. by Lara Broecke, London 2015.

Chevalier, Ulysse: Le saint Suaire de Turin, est-il l'original ou une copie? Étude critique, Chambéry 1899.

Choe, Byoung Jo: Geistiges Eigentum im römischen Recht? - unter besonderer Berücksichtigung des Urheberrechts, in: Seoul Law Journal, 52.2010 (2), 1-35.

Cropper, Elizabeth: The Domenichino Affair. Novelty, Imitation, and Theft in Seventeenth-Century Rome, New Haven/London 2005.

Dabhoiwala, Faramerz: The Appropriation of Hogarth's Progresses, in: Huntington Library Quarterly, 75.2012, 577-595.

116 U.S. Copyright Office 2014, 22

117 Malkan 2005, 425. 
Damon, Paul E. / Donahue, Douglas J. [et al.]: Radiocarbon dating of the Shroud of Turin, in: Nature, 337.1989, 611-615.

Deazley, Ronan: Struggling with Authority: The Photograph in British Legal History, in: History of Photography, 27.2003, 236-246.

Deazley, Ronan: On the Origin of the Right to Copy. Charting the Movement of Copyright Law in Eighteenth-Century Britain (1695-1775), Oxford/Portland, Or. 2004.

Delaborde, Henri: La Photographie et la gravure, in: Revue des deux mondes, 2.1856, 617-638.

Didi-Huberman, Georges: The Index of the Absent Wound (Monograph on a Stain), in: October, 29.1984, 63-81.

Didi-Huberman, Georges: La ressemblance par contact. Archéologie, anachronisme et modernité de l'empreinte, in: exh. cat. L'Empreinte (Centre Georges Pompidou, Paris 1997), ed. by Georges Didi-Huberman, Paris 1997, 15-191.

Dobschütz, Ernst v.: Christusbilder: Untersuchungen zur christlichen Legende, Leipzig 1899.

Donnadieu, Adolphe-Louis: Le saint Suaire de Turin devant la science, Paris [1903].

Dziatzko, Karl: Autor- und Verlagsrecht im Alterthum, in: Rheinisches Museum für Philologie, 49.1894, 559-576.

Egenolff, Christian: Adversum illiberales Leonharti Fuchsii, medici Tubingensis, calumnias, responsio Christiani Egenolphi, typographi Francofortani, Frankfurt/M. 1544, URL: http:// www.mdz-nbn-resolving.de/urn/resolver.pl?urn=urn:nbn:de:bvb:12-bsb10972932-6 (last access 12 October 2017).

Exh. cat. Colorful Impressions. The Printmaking Revolution in Eighteenth-Century France (Washington, DC, National Gallery of Art 2003/2004), ed. by Margaret Morgan Grasselli, Aldershot 2003.

Exh. cat. L'immagine rivelata. 1898. Secondo Pia fotografa la Sindone (Turin, Archivio di Stato di Torino, 1998), ed. by Gian Maria Zaccone, Turin 1998.

Fawcett, Trevor: Graphic Versus Photographic in the Nineteenth Century Reproduction, in: Art History, 9.1986, 185-212.

Frumkin, Maximilian: The Origin of Patents, in: Journal of the Patent Office Society, 27.1945, 143-148.

Fuchs, Leonhart: Adversus mendaces et christiano nomine indignos Christiani Egenolphi, typographi Francofortani suique architecti, calumnias, Leonharti Fuchsii responsio, Basel 1545, URL: http:// www.mdz-nbn-resolving.de/urn/resolver.pl?urn=urn:nbn:de:bvb:12-bsb11069345-9 (last access 12 October 2017).

Gambart, Ernest: On Piracy of Artistic Copyright, London 1863.

Geimer, Peter: L'autorité de la photographie - Révélations d'un suaire, in: Études photographiques, 6.1999, 67-99.

Geimer, Peter: Bilder aus Versehen. Eine Geschichte fotografischer Erscheinungen, Hamburg 2010.

Girardin, Daniel / Pirker, Christian: Controverses. Une histoire juridique et éthique de la photographie, Arles 2008.

Goodman, Nelson: Languages of Art, $2^{\text {nd }}$ ed. Indianapolis 1976.

Gouma-Peterson, Thalia: Originality in Byzantine Religious Paintings (Mosaics and Frescoes), in: Originality in Byzantine Literature, Art and Music. A Collection of Essays, ed. by A. R. Littlewood, Oxford 1995, 125-145.

Gramaccini, Norbert / Meier, Hans Jakob: Die Kunst der Reproduktion. Französische Reproduktionsgraphik 1648-1792, Munich/Berlin 2003.

Grotefend, Hermann: Christian Egenolff, der erste ständige Buchdrucker zu Frankfurt a. M. und seine Vorläufer, Frankfurt a.M. 1881.

Hamber, Anthony J.: "A Higher Branch of the Art". Photographing the Fine Arts in England, 1839-1880. Amsterdam 1996.

Hitzig, Julius Eduard: Das Königl. Preußische Gesetz vom 11. Juni 1837 zum Schutze des Eigenthums an Werken der Wissenschaft und Kunst gegen Nachdruck und Nachbildung, Berlin 1838.

[Hogarth, William, et al.:] The Case of Designers, Engravers, Etchers, \&c. Stated in a Letter to a Member of Parliament [London 1735].

Holmes, Megan: The Miraculous Image in Renaissance Florence, New Haven/London 2013.

Kaenel, Philippe: Le corps du Christ entre imaginaires photographique et graphique au XXe siècle: autour du suaire de Turin, in: Les cahiers du GRIT, 1.2011, 76-91. 
Kemp, Wolfgang (ed.): Theorie der Fotografie, vol. I: 1839-1912, Munich 1980.

Kitzinger, Ernst: The Cult of Images in the Age Before Iconoclasm, in: Dumbarton Oaks Papers, 8.1954, 83-150.

Klostermann, Rudolf: Das Urheberrecht an Schrift- und Kunstwerken, Berlin 1876.

Koerner, Joseph Leo: The Moment of Self-Portraiture in German Renaissance Art, Chicago/London 1993.

Kostylo, Joanna: From Gunpowder to Print: The Common Origins of Copyright and Patent, in: Privilege and Property. Essays on the History of Copyright, ed. by Ronan Deazley [et al.], Cambridge 2010, 21-50.

Kubler, George: The Shape of Time. Remarks on the History of Things, New Haven/London, 2007 [1962].

Kunzle, David: Plagiaries-by-Memory of the Rake's Progress and the Genesis of Hogarth's Second Picture Story, in: Journal of the Warburg and Courtauld Institutes, 29.1966, 311-348.

Kusukawa, Sachiko: Picturing the Book of Nature. Image, Text, and Argument in Sixteenth-Century Human Anatomy and Medical Botany, Chicago 2012.

Lamartine, Alphonse de: Cours familier de littérature, vol. 6, Paris 1858.

Landau, David: The print collection of Ferdinand Columbus (1488-1539), in: Collecting Prints and Drawings in Europe, c. 1500-1750, ed. by Christopher Baker, Caroline Elam [et al.], Aldershot 2003, 29-36.

Londe, Albert: La Photographie moderne. Pratique et applications, Paris 1888.

Loth, Arthur: Le portrait de N.-S. Jesus-Christ d'après le saint-Suaire de Turin, avec reproductions photographiques, Paris/Poitiers [1900].

Loth, Arthur: La photographie du Saint Suaire de Turin, Paris/Poitiers [1910].

Macartney, Hilary: William Stirling and the Talbotype Volume of the Annals of the Artists of Spain, in: History of Photography, 30.2006, 291-308.

Malkan, Jeffrey: What is a Copy?, in: Cardozo Arts and Entertainment Law Journal, 23.2005, 419-463.

Mandich, Giulio: Venetian Patents (1450-1550), in: Journal of the Patent Office Society, 30.1948, $166-224$.

Mango, Cyril A.: The Art of the Byzantine Empire 312-1453. Sources and Documents, Englewood Cliffs 1972.

McCauley, Anne: "Merely Mechanical". On the Origins of Photographic Copyright in France and Great Britain, in: Art History, 31.2008, 57-78.

Mély, Fernand de: Le Saint-Suaire de Turin est-il authentique? Les Représentations du Christ à travers les ages, Paris 1902.

Michel, Christian: Une mutation du regard. L'interprétation gravée de Raphaël de l'Ancien Régime à la Restauration, in: Interkulturelle Kommunikation in der europäischen Druckgraphik im 18. und 19. Jahrhundert, ed. by Philippe Kaenel and Rolf Reichardt, Hildesheim 2007, 591-607.

Mondzain, Marie-José: Image, Icon, Economy. The Byzantine Origins of the Contemporary Imaginary, Stanford, Cal., 2005 [first published in French as: Image, Icône, Économie. Les sources Byzantines de l'imaginaire contemporain, Paris 1996].

Mortier, Roland: L'Originalité. Une nouvelle catégorie esthétique au siècle des lumières. Geneva 1982.

Parshall, Peter: Imago Contrafacta. Images and Facts in the Northern Renaissance, in: Art History, 16.1993, 554-579.

Paulson, Ronald: Hogarth. High Art and Low, 1732-1750, Cambridge 1992.

Petri, Grischka: On the Copyright Hermeneutics of the Original, in: The Challenge of the Object/Die Herausforderung des Objekts, ed. by G. Ulrich Großmann and Petra Krutisch, 3 vols., Nuremberg 2013 [2014], vol. 1, 166-70.

Petri, Grischka: Der Fall Dürer vs. Raimondi. Vasaris Erfindung, in: Fälschung - Plagiat - Kopie, ed. by Birgit Ulrike Münch, Andreas Tacke [et al.], Petersberg 2014, 52-69.

PG Patrologia cursus completus, Series graeca, ed. by Jacques Paul Migne, 161 vols., Paris 1844-1866.

Pon, Lisa: "Alla Insegna del Giesù". Publishing Books and Pictures in Renaissance Venice", in: The Papers of the Bibliographical Society of America, 92.1998, 443-465.

Pon, Lisa: Raphael, Dürer, and Marcantonio Raimondi. Copying and the Italian Renaissance Print, New Haven/London 2004. 
Ricke, Stefan: Entwicklung des rechtlichen Schutzes von Fotografien in Deutschland unter besonderer Berücksichtigung der preußischen Gesetzgebung, Münster 1998.

Rooseboom, Hans: De schaduw van de fotograaf. Positie en status van een nieuw beroep, 1839-1889, Leiden 2008.

Rose, Mark: Technology and Copyright in 1735. The Engraver's Act, in: The Information Society, 21.2005, 63-66.

Schickert, Katharina: Der Schutz literarischer Urheberschaft im Rom der klassischen Antike, Tübingen 2005.

Stoltz, Barbara: Giovanni Bagliones Vite degli Intagliatori und die Theorie der Autorschaft - disegno, inventio, imitatio, in: Druckgraphik. Zwischen Reproduktion und Invention, ed. by Markus A. Castor, Jasper Kettner [et al.], Berlin/Munich 2010, 249-260.

Sullivan, Denis F.: The Life of Saint Nikon, Brookline, Mass., 1987.

Tatarkiewicz, Władysław: A History of Six Ideas. An Essay in Aesthetics. The Hague [et al.] 1980.

Trilling, James: The Image not Made by Hands and the Byzantine Way of Seeing, in: The Holy Face and the Paradox of Representation, ed. by Herbert L. Kessler and Gerhard Wolf, Bologna 1998, 109-127.

U.S. Copyright Office: Compendium of U.S. Copyright Office Practices, §313.2, December 2014, URL: http://copyright.gov/comp3/chap300/ch300-copyrightable-authorship.pdf (last access 12 October 2017).

Vasari, Giorgio: Le vite de' più eccellenti pittori, scultori, e architettori, 3 vols., Florence 1568.

Vasari, Giorgio: Lives of the Most Eminent Painters, Sculptors and Architects, transl. by Gaston du C. De Vere, 10 vols., London 1912-1915.

Vignon, Paul: The Shroud of Christ, Westminster 1902 [translation of: Le Linceul de Christ. Étude scientifique, 2nd ed., Paris 1902].

Vikan, Gary: Ruminations on Edible Icons. Originals and Copies in the Art of Byzantium, in: Retaining the Original. Multiple Originals, Copies, and Reproductions, ed. by Kathleen Preciado (Studies in the History of Art, 20), Washington, DC 1989, 47-59.

Wächter, Oscar: Das Urheberrecht an Werken der Bildenden Künste, Photographien und gewerblichen Mustern, Stuttgart 1877.

Weyl Carr, Annemarie: Originality and the Icon. The Panel Painted Icon, in: Originality in Byzantine Literature, Art and Music, ed. by A. R. Littlewood, Oxford 1995, 115-124.

Winthrop-Young, Geoffrey: Cultural Techniques. Preliminary Remarks, in: Theory, Culture \& Society, 30.2013, 3-19.

Witcombe, Christopher L.C. E.: Copyright in the Renaissance, Leiden 2004.

Wolf, Gerhard: Schleier und Spiegel. Traditionen des Christusbildes und die Bildkonzepte der Renaissance, Munich 2002.

Wood, Christopher S.: Forgery, Replica, Fiction. Temporalities of German Renaissance Art, Chicago 2008.

Zaccone, Gian Maria: La Fotografia della Sindone del 1898, in: exh. cat. Turin 1998, 19-29. 